\title{
触 New Disease Reports \\ First report of Moko disease caused by Ralstonia solanacearum race 2 in plantain (Musa AAB) in Ecuador
}

\author{
R. Delgado*, E. Morillo, J. Buitrón, A.Bustamante and I. Sotomayor \\ Instituto Nacional Autónomo de Investigaciones Agropecuarias (INIAP), Quito, Ecuador \\ *E-mail: ricardo.delgado@iniap.gob.ec
}

Received: 11 Sep 2014. Published: 03 Nov 2014. Keywords: Wilt, bacteria, Musaceae

In October 2013, in a plantain farm in El Carmen canton in Manabí, Ecuador, the occurrence of wilted plants of cv. Barraganete with necrosis in vascular tissue of rhizomes and pseudostem was observed. Fruits were observed to ripen prematurely and exhibited an internal dry rot. Reddish necrotic spots were also noted in the rachis of the diseased bunches (Fig 1). Symptoms resembled those described for Moko disease by Thwaites $e$ al. (2000). Samples were taken to the Litoral Sur Experimental Station of INIAP for pathogen identification. A whitish ooze exuded from the vascular vessels of affected fruits when suspended in clean water. Pieces of infected tissue from rhizome and fruits were macerated in distilled water then plated onto triphenyl tetrazolium chloride (TZC) medium (Kelman, 1954). The resulting isolates of bacteria were tested for solubility in $\mathrm{KOH}$, growth in King's B, nutrient agar (NA) and yeast extract-dextrose-calcium carbonate (YDC) media, and soft-rotting activity on potato slices. The resulting colonies were Gram negative according to their reaction with $\mathrm{KOH}$, non-fluorescent in King's B, had cream colour in YDC and NA, had a reddish centre with white periphery on TZC (Fig. 2), and did not rot potato slices.

Pathogenicity tests were conducted on banana plants cv. Williams in a greenhouse by pseudostem inoculation with a bacterial suspension, and incubated at $26.5^{\circ} \mathrm{C}$. Necrotic symptoms were observed at the infection point after eight days. Yellowing was observed after three weeks. Reisolation on TZC medium confirmed Koch's postulates. Molecular detection was carried out using three combinations of markers: OLI-1/Y-2, Ps-1/Ps-2 and 759/760 with detection fragments of 288, 553 and 282 bp respectively (Seal et al., 1993; Opina et al., 1997; Pastrik \& Maiss, 2000). All bacterial isolates tested rendered the expected fragments for $R$. solanacearum (for example, $282 \mathrm{bp}$ fragments from primers $759 / 760$ as shown in Fig. 3). Based on the bacterial characteristics, pathogenicity test on banana and PCR, we concluded that Ralstonia solanacearum race 2 caused the wilt of plantain plants observed. The bacteria probably arrived at this location on planting material brought from Colombia where the pathogen had been recognised since the 1960s (Castaneda \& Espinosa, 2005). To date there is no other report of the bacteria outside El Carmen. This is the first report of the occurrence of the $R$. solanacearum in the
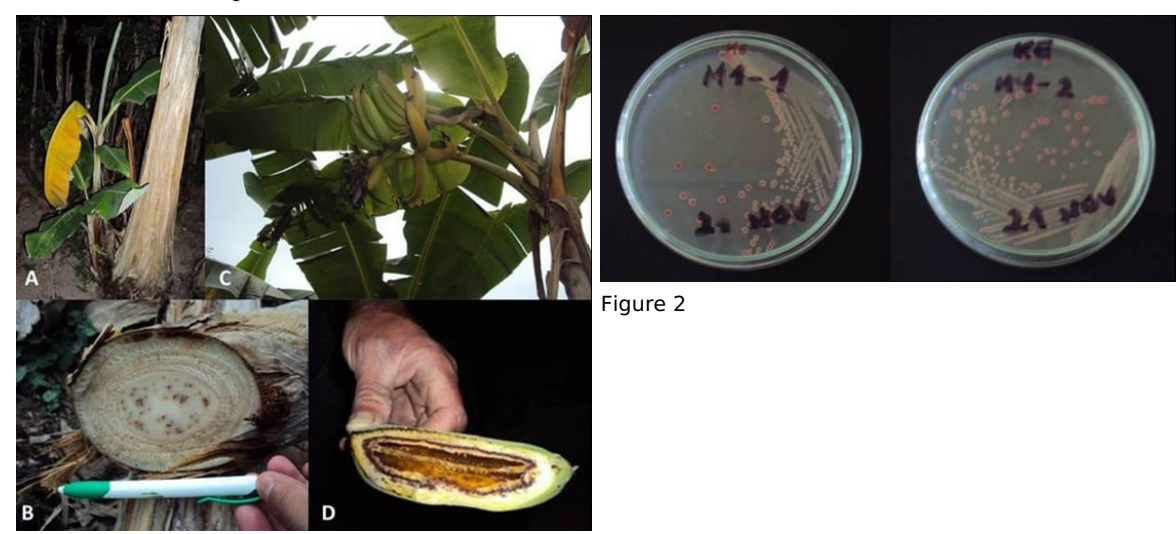

Figure 2

Figure 1 coastal area of Ecuador in this crop. Further work is necessary for more refined categorisation of the pathogen in terms of biochemical profile or nucleotide sequence.

\section{Acknowledgements}

The authors would like to thank Mr. Jorge Vivas for his assistance during the visit to the affected farms.

\section{References}

Castañeda DA, Espinosa JA, 2005. Comportamiento e impacto de la enfermedad de moko en la zona de Urabá (Colombia), en las últimas tres décadas y media y propuesta de un indice de riesgo de la enfermedad. Revista Facultad Nacional de Agronomía Medellin 58, 2587-2599.

Kelman A, 1954. The relationship of pathogenicity in Pseudomonas solanacearum to colony appearance on a tetrazolium medium. Phytopathology 44, 693-695.

Opina N, Tavner F, Hollway G, Wang JF, Li TH, Maghirang R, Fegan M, Hayward AC, Krishnapillai V, Hong WF, Holloway BW, Timmis JN, 1997. A novel method for development of species and strain-specific DNA probes and PCR primers for identifying Burkholderia solanacearum (formerly Pseudomonas solanacearum). Asia-Pacific Journal of Molecular Biology and Biotechnology 5, 19-30.

Pastrik KH, Maiss E. 2000. Detection of Ralstonia solanacearum in potato tubers by polymerase chain reaction. Journal of Phytopathology $\mathbf{1 4 8}$, 619-626. http://dx.doi.org/10.1111/j.1439-0434.2000.00567.x

Seal SE, Jackson LA, Young JPW, Daniels MJ. 1993. Differentiation of Pseudomonas solanacearum, Pseudomonas syzygii, Pseudomonas pickettii and the Blood Disease Bacterium by partial 16S rRNA sequencing: construction of oligonucleotide primers for sensitive detection by polymerase chain reaction. Microbiology 139, 1587-1594.

Thwaites R, Eden-Green SJ, Black R, 2000. Diseases caused by bacteria. In: Jones DR, ed. Diseases of Banana, Abacá and Enset. Wallingford, UK: CABI, 213-239.

To cite this report: Delgado R, Morillo E, Buitrón J, A.Bustamante, Sotomayor I, 2014. First report of Moko disease caused by Ralstonia solanacearum race 2 in plantain (Musa AAB) in Ecuador. New Disease Reports 30, 23. http://dx.doi.org/10.5197/j.2044-0588.2014.030.023 (c) 2014 The Authors

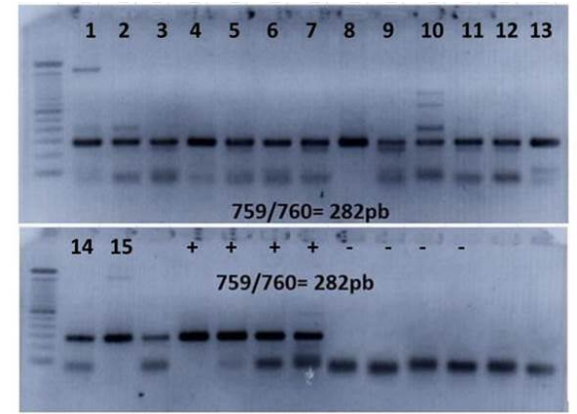

Figure 3 